\title{
Properly Timed Soil-applied Nitrogen Fertilizer Increases Yield and Fruit Size of 'Hass' Avocado
}

\author{
Carol J. Lovatt ${ }^{1}$ \\ Department of Botany and Plant Sciences, University of California, Riverside, CA 92521-0124
}

\begin{abstract}
AdDitional INDEX wORDs. phenology, alternate bearing, Persea americana
Abstract. To protect groundwater from potential nitrate pollution, 'Hass' avocado (Persea americana Mill.) growers in California divide the total annual soil-applied nitrogen $(\mathrm{N})$ fertilizer ( $\mathrm{N}$ at 56 to $\left.168 \mathrm{~kg} \cdot \mathrm{ha}^{-1}\right)$ into small applications made during the period from late January to early November. However, no research had been conducted to test the efficacy of this fertilization practice, and there was concern that the amount of $\mathrm{N}$ in the individual applications may be too little to meet the demand of the tree at some stages of its phenology. The research presented herein addressed the question of whether yield of 'Hass' avocado could be increased by doubling the amount of $\mathrm{N}$ currently applied during specific stages

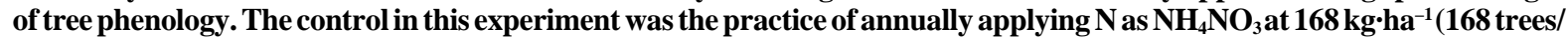
ha) in six small doses of $\mathrm{N}$ at $28 \mathrm{~kg} \cdot \mathrm{ha}^{-1}$ in January, February, April, June, July, and November. From these six application times, five were selected on the basis of tree phenology and additional $\mathrm{N}$ as $\mathrm{NH}_{4} \mathrm{NO}_{3}$ at $28 \mathrm{~kg} \cdot \mathrm{ha}^{-1}$ was applied at each time for total annual $\mathrm{N}$ of $196 \mathrm{~kg} \cdot \mathrm{ha}^{-1}$. Two phenological stages were identified for which $\mathrm{N}$ application at $56 \mathrm{~kg} \cdot \mathrm{ha}^{-1}$ in a single application (double dose of $\mathrm{N}$ ) significantly increased the 4-year cumulative yield (kilograms fruit per tree) $30 \%$ and $39 \%$, respectively, compared to control trees $(P \leq 0.01)$. In each case, more than $70 \%$ of the net increase in yield was commercially valuable large size fruit ( 178 to $325 \mathrm{~g}$ /fruit). The two phenological stages were when shoot apical buds have four or more secondary axis inflorescence meristems present (mid-November); and during anthesis to early fruit set and initiation of the vegetative shoot flush at the apex of indeterminate floral shoots (about mid-April). When the double dose of $N$ was applied at either of these two stages, the kilograms and number of large size fruit averaged across the 4 years of the study was significantly greater than the control trees $(P \leq 0.01)$. Averaged across the 4 years of the study, only the November treatment increased yield compared to the control trees $(P \leq 0.05)$. Application of the double dose of $N$ at flower initiation (January), during early-stage gynoecium development (February), or during June drop had no significant effect on average or cumulative yield or fruit size compared to control trees. Application of the double dose of $\mathrm{N}$ in April significantly reduced the severity of alternate bearing $(P \leq 0.05)$. Yield was not significantly correlated with leaf $N$ concentration. Time and rate of $\mathrm{N}$ application are factors that can be optimized to increase yield, fruit size, and annual cropping of 'Hass' avocado. When the amounts of $\mathrm{N}$ applied were equal $\left(196 \mathrm{~kg} \cdot \mathrm{ha}^{-1}\right)$, time of application was the more important factor.
\end{abstract}

The first research on $\mathrm{N}$ fertilization of avocado (Persea americana) in California was with 'Fuerte' (Embleton et al., 1955, 1959). The optimal $N$ range for maximum 'Fuerte' yield was $1.6 \%$ to $2.0 \% \mathrm{~N}$ in spring flush leaves sampled between midAugust and October. 'Fuerte' yield decreased when leaf $\mathrm{N}$ concentration was below or above this range (Embleton and Jones, 1965). Subsequent N nutrition research with 'Hass' indicated that yield did not decrease when leaf $\mathrm{N}$ concentrations exceeded 2.0\%. Despite the fact that different rates of $\mathrm{N}$ fertilization resulted in significant differences in leaf $\mathrm{N}$ concentrations, there was no correlation with yield in a given year. However, this 5-year experiment documented that 'Hass' avocado trees had the highest mean yield at the highest yearly rate of $\mathrm{N}$ fertilization (1.8 $\mathrm{kg} / \mathrm{tree}$ ). Mean leaf $\mathrm{N}$ concentration was $2.13 \%$ for this treatment (Embleton et al., 1968).

In a second $\mathrm{N}$ fertilization experiment, 6-year-old 'Hass' avocado trees fertilized with low rates of $\mathrm{N}$ had low leaf $\mathrm{N}$ concentrations. However, four different annual rates of $\mathrm{N}$ from

Received for publication 24 Aug. 2000. Accepted for publication 22 May 2001. This research was supported in part by the Citrus Research Center and Agricultural Experiment Station of the Univ. of California, Riverside, and by the California Avocado Commission. The author thanks Anwar Ali, Calixto Protacio, Larry Summers, and Yusheng Zheng for technical assistance and Grant Klein for statistical analysis of the data. Special thanks to Len Francis, L.F. Grove Management, for the use of the orchard and for assisting us with the four harvests. The cost of publishing this paper was defrayed in part by the payment of page charges. Under postal regulations, this paper must be hereby marked advertisement solely to indicate this fact.

${ }^{1}$ Professor of plant physiology.
0.1 to $1.8 \mathrm{~kg} /$ tree applied by splitting the total $\mathrm{N}$ in July and November or in February, July, and November had no effect on yield over a 7-year period (Embleton and Jones, 1972). The results suggested that 'Hass' avocado yields were insensitive to $\mathrm{N}$ fertilization rates, time of application, and leaf $\mathrm{N}$ concentrations in the range between $1.75 \%$ and $2.12 \%$. Langenegger and Koen (1978), Lahav et al. (1990), and Lahav (1998) demonstrated similarly that 'Fuerte', 'Ardith' and 'Ettinger' avocado trees responded poorly to different fertilization regimes and that high rates of $\mathrm{N}$ fertilization decreased yield of 'Fuerte'. Kalmer and Lahav (1976) and Kotzé (1982) proposed that N fertilization during fruit set would stimulate growth of the vegetative shoot at the apex of indeterminate floral shoots and reduce fruit set and yield as a result of competition for resources. Kotzé (1982) proposed that the optimal time for fertilization would be from June through November (translated to the Northern Hemisphere). This period includes June drop (June and July), the period of rapid increase in fruit size (August through October), and seed maturity (November).

In the early years of avocado production in California, a single soil $\mathrm{N}$ application was made between January and March, or half the $\mathrm{N}$ was applied at that time and the remainder in June or July (Bekey, 1989). When $\mathrm{N}$ was applied through the irrigation system, the recommendation was to apply the total annual $\mathrm{N}$ in small doses at the beginning of each month or at least every month from March through October (Bekey, 1989). To protect groundwater from potential nitrate pollution, California avocado growers were encouraged to apply the total annual $\mathrm{N}$ in six small doses, about every other month beginning in January without regard for 
changes in $\mathrm{N}$ demand associated with different stages of tree phenology. Whereas there are theories on right and wrong times to fertilize avocado trees, the relationship between critical periods of tree phenology and the effect of application time and amount of fertilizer applied at specific times have not been adequately investigated (Lahav, 1998).

In the 4-year study presented herein, we quantified the effect on yield of applying a double dose of $N\left(56 \mathrm{~kg} \cdot \mathrm{ha} \mathrm{a}^{-1}\right)$ at one of several key times in the phenology of the 'Hass' avocado tree that were already included as one of the six application times in the grower practice. The application times included in the grower practice corresponded to the following phenological stages and calendar dates: 1) end of vegetative shoot growth, shoot apices have about four secondary axes of the inflorescence present, additional secondary axes are being initiated (November); 2) early bud swell $=$ the total number of secondary axes (10) of the inflorescence are formed, the oldest are beginning to elongate and to initiate flower organs (January); 3) buds swollen = the youngest secondary axes of the inflorescence are elongating, oldest secondary axes have fully formed flowers with the gynoecium in the early stages of development (February); 4) anthesis to early fruit set and initiation of the spring vegetative flush at the apex of indeterminate floral shoots (April); 5) end of Stage I (initial cell division phase) of fruit development and beginning of the June drop period (June); and 6) beginning of Stage II of fruit development (rapid increase in fruit size) and end of the June drop period (July) (Salazar-Garcia and Lovatt, 1998). The objective was to identify the optimal $\mathrm{N}$ fertilization strategy to obtain maximum yield, fruit size, and annual cropping of 'Hass' avocado.

\section{Materials and Methods}

Plant material. This experiment used 20-year-old 'Hass' avocado trees on 'Duke 7' clonal rootstock in a commercial orchard, originally planted at $4.9 \times 6.0 \mathrm{~m}$ spacing and subsequently thinned by removing about every other tree in the row to a final density of 168 trees/ha. The orchard was located in Temecula, Calif. (lat. $34^{\circ} \mathrm{N}$ ). The soil was a sandy loam with a decomposed granite base in the Cajalco series. The experiment was initiated in November before an off-year bloom, i.e., the trees were carrying a heavy on-year crop.

NiTROGEN TREATMENTS. All trees received annually with irrigation $\mathrm{N}$ as $\mathrm{NH}_{4} \mathrm{NO}_{3}$ at $168 \mathrm{~kg} \cdot \mathrm{ha}^{-1}$ divided into six $\mathrm{N}$ applications at $28 \mathrm{~kg} \cdot \mathrm{ha}^{-1}$ made in mid-January, mid-February, mid-April, mid-June, mid-July, and mid-November. Control trees received no additional $\mathrm{N}$ fertilizer. Treated trees received additional $\mathrm{N}$ as $\mathrm{NH}_{4} \mathrm{NO}_{3}$ at $28 \mathrm{~kg} \cdot \mathrm{ha}^{-1}$ at one of five stages of tree phenology (the approximate calendar date is given in parentheses): 1) end of vegetative shoot growth, shoot apices have a minimum of four secondary axes of the inflorescence present, additional secondary axes are being initiated (mid-November); 2) early bud swell = the total number of secondary axes (10) of the inflorescence are formed, the oldest are beginning to elongate and to initiate flower organs (mid-January); 3 ) buds swollen = the youngest secondary axes of the inflorescence are elongating, oldest secondary axes have fully formed flowers with the gynoecium in the early stages of development (mid-February); 4) anthesis to fruit set and initiation of the spring vegetative flush at the apex of indeterminate floral shoots (mid-April); and 5) end of Stage I (initial cell division phase) of fruit development and beginning of the June drop period (mid-June) (Salazar-Garcia and Lovatt, 1998). Treated trees received annual total $\mathrm{N}$ as $\mathrm{NH}_{4} \mathrm{NO}_{3}$ at $196 \mathrm{~kg} \cdot \mathrm{ha}^{-1}$.
In September of each year, 20 spring flush leaves from nonfruiting terminals were collected uniformly around each data tree at $1.5 \mathrm{~m}$ above the ground. Leaves were washed with soapy water and rinsed thoroughly with distilled water, oven dried at 60 ${ }^{\circ} \mathrm{C}$ for $72 \mathrm{~h}$, and ground in a Wiley mill to pass through a 40-mesh (0.635-mm) screen (Embleton et al., 1973). The ground samples were sent to Albion Laboratories, Clearfield, Utah, for mineral nutrient analysis. Samples were combusted at $1050{ }^{\circ} \mathrm{C}$ and $\mathrm{N}$ was determined by thermal conductivity (Leco Corp., St. Joseph, Mich.).

In year 1, fruit were harvested in March, 11 months after bloom. In year 2 , large fruit were harvested in February, $\approx 10$ months after bloom; the remaining fruit were harvested at the end of July. In year 3, all fruit were harvested 15 months after bloom at the end of July. In year 4, fruit were harvested in early May, $\approx 12$ months after bloom. Total yield was determined as kilograms fruit per tree. A randomly selected subsample of 100 to 150 fruit per tree, representing $\approx 20 \%$ to $100 \%$ of the fruit on the tree, was collected for each data tree. The weight of each fruit in the subsample was determined. These data were used to determine pack-out, i.e., the kilograms of each packing carton size per tree, and to estimate the total number of fruit per tree. The following packing carton fruit sizes (grams per fruit) were used: size 84 (99 to $134 \mathrm{~g}$ ), size 70 (135 to $177 \mathrm{~g}$ ), size 60 (178 to $212 \mathrm{~g}$ ), size 48 (213 to $269 \mathrm{~g}$ ), size 40 (270 to $325 \mathrm{~g}$ ), size 36 (326 to $354 \mathrm{~g}$ ), and size 32 (355 to $397 \mathrm{~g}$ ).

In addition, at harvest, two fruit were selected randomly per tree and allowed to ripen in a controlled temperature chamber at 18 to $21^{\circ} \mathrm{C}$. When ripe, external and internal fruit quality were evaluated for abnormalities and discoloration. Vascularization (presence of vascular bundles and associated fibers) of the flesh was also determined. The above fruit quality parameters were rated on a scale from 0 (normal) to 4 (high incidence of abnormalities, discoloration, or vascularization).

Alternate bearing index (ABI) was calculated for each sequential 2-year period using the equation: $\mathrm{ABI}(\%)=($ year 1 yield in kilograms minus year 2 yield)/(sum of year 1 yield in kilograms plus year 2 yield) $\times 100$.

Statistical analysis. The experimental design with 20 singletree replications per treatment was a randomized complete block. Repeated measure analysis was used to test treatment effects on yield parameters with year as the repeated measure factor (Table 1). This analysis was performed using General Linear Model procedures of the SAS statistical program (SAS Inst., Inc., Cary, N.C.). Analysis of variance was used to test treatment effects on leaf analyses and on all yield parameters for a specific year and for the 4-year cumulative yield (Tables 2-5). Linear regression analysis was used to test the effect of yield on fruit size (Fig. 1) or on leaf total $\mathrm{N}$ concentration and the effect of rainfall on yield. Means were separated using Duncan's multiple range test at $P \leq$ 0.05 . Note that for 4 -year cumulative yields, a missing datum point for a tree in any year excluded all the data for that tree from the statistical analysis.

\section{Results}

Yield RESPONSE TO THE AMOUNT AND TIME OF N APPLICATION. When averaged over the 4 years of the experiment, those trees that received a double dose of $\mathrm{N}\left(56 \mathrm{~kg} \cdot \mathrm{ha}^{-1}\right)$ in November had significantly more yield as kilograms fruit per tree compared to the control trees; number of fruit per tree was not affected (Table 1). Trees receiving a double dose of $\mathrm{N}$ in April had yields that 
Table 1. Effect of time and amount of soil-applied N across 4 years on yield of 'Hass' avocado.

\begin{tabular}{|c|c|c|c|c|c|c|}
\hline \multirow[b]{3}{*}{$\begin{array}{l}\text { Month extra } \\
\mathrm{N} \text { applied }\end{array}$} & \multicolumn{6}{|c|}{ Yield/tree } \\
\hline & \multicolumn{2}{|c|}{ All fruit } & \multicolumn{2}{|c|}{ Fruit packing carton sizes $40-60$} & \multicolumn{2}{|c|}{ Fruit packing carton sizes $70-84$} \\
\hline & $\begin{array}{l}\text { Total wt } \\
\text { (kg) }\end{array}$ & No. & $\begin{array}{c}\text { Total wt } \\
(\mathrm{kg})\end{array}$ & No. & $\begin{array}{l}\text { Total wt } \\
(\mathrm{kg})\end{array}$ & No. \\
\hline None $^{\mathrm{z}}$ (control) & $58.5 \mathrm{bc}^{\mathrm{y}}$ & $306 \mathrm{ab}$ & $38.4 \mathrm{~b}$ & $166 \mathrm{~b}$ & 20.1 & $\overline{135.8}$ \\
\hline January & $56.1 \mathrm{bc}$ & $284 \mathrm{~b}$ & $34.9 \mathrm{~b}$ & $152 \mathrm{~b}$ & 19.4 & 129.7 \\
\hline February & $56.1 \mathrm{bc}$ & $280 \mathrm{~b}$ & $31.7 \mathrm{~b}$ & $140 \mathrm{~b}$ & 20.6 & 139.0 \\
\hline April & $71.8 \mathrm{ab}$ & $349 a b$ & $55.1 \mathrm{a}$ & $234 \mathrm{a}$ & 16.6 & 111.0 \\
\hline June & $53.2 \mathrm{c}$ & $272 b$ & $38.1 \mathrm{~b}$ & $162 \mathrm{~b}$ & 16.2 & 107.7 \\
\hline November & $76.5 \mathrm{a}$ & $384 \mathrm{a}$ & $54.9 \mathrm{a}$ & $235 \mathrm{a}$ & 21.5 & 145.4 \\
\hline \multicolumn{7}{|c|}{ Significance of $\mathrm{F}$ test ${ }^{\mathrm{x}}$} \\
\hline $\mathrm{N}$ & $*$ & $*$ & $* *$ & $* * *$ & NS & NS \\
\hline Year & $* * * *$ & $* * * *$ & $* * * *$ & $* * * *$ & $* * * *$ & $* * * *$ \\
\hline $\mathrm{N} \times$ year & $*$ & NS & NS & NS & NS & NS \\
\hline
\end{tabular}

${ }^{\mathrm{z} S t a n d a r d ~ g r o w e r ~ p r a c t i c e . ~}$

yMean separation within the columns by Duncan's multiple range test, $P \leq 0.05$.

${ }^{x}$ Data analyzed using repeated measures model with year as the repeated measures factor.

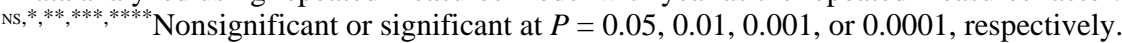

were intermediate to and not significantly different from trees receiving a double dose of $\mathrm{N}$ in November and control trees. Trees receiving a double dose of $\mathrm{N}$ in June had significantly lower yields (kilograms fruit per tree) averaged over the 4 years of the study than trees receiving a double dose of $\mathrm{N}$ in November or April. A double dose of $\mathrm{N}$ in November or April significantly increased the kilograms and number of commercially valuable large size fruit per tree averaged over the 4 years of the study (Table 1). Regression analysis demonstrated there was a significant positive relationship between yield (total kilograms fruit per tree) and the number of commercially desirable large size fruit per tree, i.e., fruit weighing from 178 to $325 \mathrm{~g}$ per fruit (packing carton sizes 60 to 40) (Fig. 1). Likewise, the kilograms of large size fruit weighing 178 to $325 \mathrm{~g}$ also increased significantly as total kilograms fruit per tree increased $\left(r^{2}=0.84, P=0.0001\right)$ (data not presented). Averaged over the 4 years of the study, $\mathrm{N}$ treatments did not significantly affect the kilograms or number of small fruit per tree, i.e., fruit weighing 177 to $99 \mathrm{~g}$ per fruit (packing carton size 70 to 84) (Table 1). Independent of treatment, there was a significant relationship between the kilograms, or number of fruit, of packing carton sizes 70 and 84 per tree and total kilograms fruit per tree $\left(r^{2}=0.65, P=0.0001\right)$ (data not presented). Year had a significant effect on kilograms and number of large and small size fruit per tree (Table 1). There was no significant treatment by year interaction on fruit size (Table 1).

The significant year by $\mathrm{N}$ treatment interaction on yield was likely due to alternate bearing. The alternate-bearing index for the control trees for years 1 and 2, years 2 and 3, and years 3 and 4 averaged $90 \%$ (Table 2). Nitrogen treatments significantly affected the degree of alternate bearing between years 1 and 2 and years 2 and 3 but not years 3 and 4 . The 4 -year average alternatebearing index was significantly affected by $\mathrm{N}$ treatments. A significantly lower index of alternate bearing relative to the control was achieved by annual application of $\mathrm{N}$ at $56 \mathrm{~kg} \cdot \mathrm{ha}^{-1}$ in April (Table 2).

Due to individual tree variation resulting from alternate bearing, the effect of a double dose of $\mathrm{N}$ on yield (kilograms fruit per tree) was not significant for any given year after the first year. However, application time significantly affected cumulative yield (Table 3). Trees receiving a double dose of $\mathrm{N}$ in November had significantly higher 4-year cumulative yield compared to all other treatments except trees receiving the double dose of $\mathrm{N}$ in April. The 4-year cumulative yield was significantly greater for trees receiving a double dose of $\mathrm{N}$ in April than control trees or trees receiving a double dose of $\mathrm{N}$ in January or February, but equal to those of trees receiving a double dose of $\mathrm{N}$ in June or November. The 4-year cumulative yield of commercially valuable large size fruit (packing carton sizes 60, 48, and 40, each and as the combined pool) per tree was significantly greater for trees receiving a double dose of $\mathrm{N}$ in November than control trees (Table 4). Trees receiving a double dose of $\mathrm{N}$ in April had significantly more fruit of packing carton size 40 per tree and tended to have more fruit of packing carton sizes 60 and 48 . Thus, the combined pool of fruit of packing carton sizes 60,48 , and 40 was significantly greater than the control for the 4-year cumulative yield.

Tree n Status. There was no significant treatment effect on

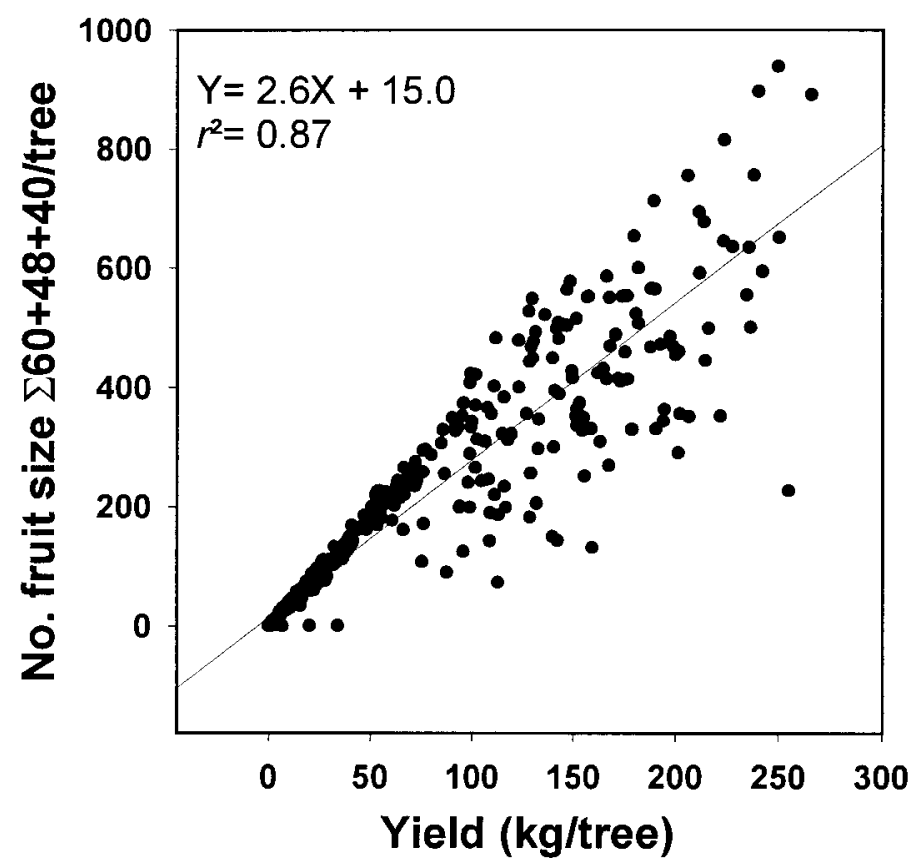

Fig. 1. Number of fruit of packing carton sizes 60 (178 to $212 \mathrm{~g} /$ fruit), 48 (212 to $269 \mathrm{~g} /$ fruit), and 40 (270 to $325 \mathrm{~g} /$ fruit) per tree as a function of total yield (kilograms fruit) per tree for the 4 years of the study $(n=465)(P=0.0001)$. 
Table 2. Effect of time and amount of soil-applied N on alternate-bearing index.

\begin{tabular}{lcccc}
\hline \hline Month extra & \multicolumn{4}{c}{ Alternate-bearing index } \\
\cline { 2 - 5 } N applied & Years 1-2 & Years 2-3 & Years 3-4 & 4-Year avg \\
\hline None $^{\mathrm{z}}$ (control) & $77 \mathrm{a}^{\mathrm{y}}$ & $98 \mathrm{a}$ & 87 & $90 \mathrm{a}$ \\
January & $70 \mathrm{ab}$ & $83 \mathrm{ab}$ & 88 & $79 \mathrm{ab}$ \\
February & $83 \mathrm{a}$ & $98 \mathrm{a}$ & 95 & $92 \mathrm{a}$ \\
April & $65 \mathrm{ab}$ & $75 \mathrm{~b}$ & 76 & $72 \mathrm{~b}$ \\
June & $78 \mathrm{a}$ & $89 \mathrm{ab}$ & 88 & $85 \mathrm{ab}$ \\
November & $53 \mathrm{~b}$ & $89 \mathrm{ab}$ & 84 & $75 \mathrm{ab}$ \\
F test & $* *$ & $*$ & NS & $*$ \\
\hline
\end{tabular}

${ }^{\mathrm{z}}$ Standard grower practice.

'Mean separation within columns by Duncan's multiple range test, $P \leq$ 0.05 .

Ns, ${ }^{*}, * *$ Nonsignificant or significant at $P=0.05$ or 0.01 , respectively.

total leaf $\mathrm{N}$ concentration until year 4 (Table 5). Year 4 leaf $\mathrm{N}$ concentrations were significantly lower than year 1 concentrations for each treatment $(P \leq 0.01)$ (data not presented). Yield was not significantly correlated with leaf total $\mathrm{N}$ concentration in any year of the study. For the 4 years of the study, $r^{2}=0.0067$.

Fruit Quality. With the exception of year 2 , the amount or time of $\mathrm{N}$ applied had no effect on external or internal fruit quality. In year 2, large fruit were harvested in February (10 months after bloom); remaining fruit were harvested at the end of July. The fruit harvested in February from the control trees had significantly lower internal fruit quality characterized by more discolored tissue and more vascular tissue present in the flesh compared to all other treatments. The two quality factors averaged 2.0 and 2.3 , respectively, on a scale from 0 (normal) to 4 (high incidence of discoloration or vascularization). Trees receiving a double dose of $\mathrm{N}$ in November had significantly better fruit quality than all other treatments, averaging 0.4 for internal quality and 1.3 for vascularization of the flesh. Trees receiving a double dose of $\mathrm{N}$ in January, February, or June ranked intermediate in quality and were not significant from each other.

\section{Discussion}

The unique feature of the approach used in this research was to provide a double dose of $\mathrm{N}\left(56 \mathrm{~kg} \cdot \mathrm{ha}^{-1}\right)$ to 'Hass' avocado trees at phenological stages with the potential for a high demand for $\mathrm{N}$. Thus, all trees received $\mathrm{N}$ at $196 \mathrm{~kg} \cdot \mathrm{ha}^{-1}$ except the control trees, which only received $\mathrm{N}$ at $168 \mathrm{~kg} \cdot \mathrm{ha}^{-1}$. A double dose of $\mathrm{N}$ significantly increased yield averaged across the 4 years of the study only when it was applied in November. Only when the double dose of $\mathrm{N}$ was applied in November or April did it increase the kilograms and number of large size fruit (178 to $325 \mathrm{~g} /$ fruit) per tree averaged across the 4 years of the study. The average alternate-bearing index for the 4 years of the study was reduced only when the double dose of $\mathrm{N}$ was applied in April. Taken together, these results provide strong evidence that time of application had a more important effect on yield parameters than the amount of $\mathrm{N}$ applied in this experiment.

The yield increases obtained in this study were not likely due to the improved $\mathrm{N}$ status of the trees by the additional $\mathrm{N}$ at 28 $\mathrm{kg} \cdot \mathrm{ha}^{-1}$, because all trees receiving the additional $\mathrm{N}$ did not exhibit increased yield, larger fruit size or reduced alternate bearing. All trees were $\mathrm{N}$ sufficient at the start of the experiment, since they had average leaf $\mathrm{N}$ levels of $2.1 \%$ or greater (Embleton et al., 1968). Total $N$ concentration of the leaves decreased significantly from year 1 to year 4 for each treatment, respectively. By year 4 , only trees that received a double dose of $\mathrm{N}$ in April had leaf $\mathrm{N}$ concentrations that remained at the level considered optimal for the 'Hass' avocado in California (i.e., 2.0\%; Guy Witney, California Avocado Commission, personal communication). Lack of correlation between total leaf $\mathrm{N}$ concentration and yield of the 'Hass' avocado has been reported previously (Embleton and Jones, 1972; Embleton et al., 1968; Lahav, 1998; Meyer et al., 1991). Embleton et al. (1968) noted that for 6- to 13-year-old trees, yield was insensitive to annual $\mathrm{N}$ fertilization rates from 0.1 to $1.8 \mathrm{~kg} /$ tree, time of application, and leaf $\mathrm{N}$ concentrations between $1.75 \%$ to $2.12 \%$. However, trees fertilized with the highest $\mathrm{N}$ rate $(1.8 \mathrm{~kg} /$ tree $)$ had the highest total leaf $\mathrm{N}$ concentration and the highest yield. In our experiment, 20-year-old trees received $\mathrm{N}$ annually at 1.0 or $1.2 \mathrm{~kg} /$ tree. The significant decrease in total leaf $\mathrm{N}$ concentration by year 4 suggests that even the higher rate of $\mathrm{N}$ fertilization was insufficient to maintain yield and $2.0 \%$ total leaf $\mathrm{N}$ concentration, with the exception of the April application. It was of interest that total leaf $\mathrm{N}$ concentrations were low in trees consistently producing low yields, i.e., yields equal to those of the control trees, but receiving additional $\mathrm{N}$ at 28 $\mathrm{kg} \cdot \mathrm{ha}^{-1}$ in January or February. Only trees receiving the double dose of $\mathrm{N}$ in June had consistently low yields but total leaf $\mathrm{N}$ concentrations significantly greater than leaves of control trees. This raised the issue of whether winter rain might be leaching $\mathrm{N}$ fertilizer applied in January and February. Regression analysis demonstrated there was no significant relationship between rainfall in January, February, April, June, or November and yield for trees receiving the double dose of $\mathrm{N}$ in those months, respectively, for the 4 years of the study (data not presented). Taken

Table 3. Effect of time and amount of soil-applied $\mathrm{N}$ on annual and cumulative yield per tree.

\begin{tabular}{|c|c|c|c|c|c|}
\hline \multirow{2}{*}{$\begin{array}{l}\text { Month extra } \\
\mathrm{N} \text { applied }\end{array}$} & \multicolumn{4}{|c|}{ Year } & \multirow{2}{*}{$\begin{array}{c}\text { 4-Year } \\
\text { cumulative yield }\end{array}$} \\
\hline & 1 & 2 & 3 & 4 & \\
\hline \multicolumn{6}{|c|}{$\mathrm{kg}$ fruit/tree } \\
\hline None $^{z}$ (control) & $47.6 a b c^{y}$ & 150.6 & 20.1 & 33.4 & $220.8 \mathrm{c}$ \\
\hline January & $36.0 \mathrm{bc}$ & 138.3 & 19.4 & 34.8 & $218.9 \mathrm{c}$ \\
\hline February & $24.1 \mathrm{c}$ & 146.7 & 9.8 & 32.4 & $212.9 \mathrm{c}$ \\
\hline April & $82.4 \mathrm{a}$ & 109.1 & 47.0 & 50.4 & $287.9 \mathrm{ab}$ \\
\hline June & $37.6 \mathrm{bc}$ & 139.4 & 13.8 & 37.6 & $231.5 \mathrm{bc}$ \\
\hline November & $67.4 \mathrm{ab}$ & 150.9 & 15.9 & 71.9 & $306.1 \mathrm{a}$ \\
\hline F test & $*$ & NS & NS & NS & $* *$ \\
\hline
\end{tabular}

${ }^{\mathrm{z}}$ Standard grower practice.

yMean separation within columns by Duncan's multiple range test, $P \leq 0.05$.

Ns,*,*** Nonsignificant or significant at $P=0.05$ or 0.01 , respectively. 
Table 4. Effect of time and amount of soil-applied $\mathrm{N}$ on the 4-year cumulative yield of commercially valuable fruit of packing carton sizes 60,48 , and 40 .

\begin{tabular}{lcccc}
\hline \hline & \multicolumn{4}{c}{ 4-Year cumulative yield (kg fruit/tree) } \\
\cline { 2 - 5 } Month extra & 60 & 48 & 40 & $\sum 60+48+40$ \\
N applied & $(178-212 \mathrm{~g})$ & $(213-269 \mathrm{~g})$ & $(270-325 \mathrm{~g})$ & $(178-325 \mathrm{~g})$ \\
\hline None $^{\mathrm{z}}$ (control) & $48.5 \mathrm{~b}^{\mathrm{y}}$ & $64.9 \mathrm{bc}$ & $28.8 \mathrm{c}$ & $142.2 \mathrm{~b}$ \\
January & $50.4 \mathrm{ab}$ & $57.2 \mathrm{bc}$ & $26.9 \mathrm{c}$ & $134.5 \mathrm{~b}$ \\
February & $51.2 \mathrm{ab}$ & $52.0 \mathrm{c}$ & $23.8 \mathrm{c}$ & $127.0 \mathrm{~b}$ \\
April & $66.9 \mathrm{ab}$ & $87.8 \mathrm{ab}$ & $57.5 \mathrm{a}$ & $212.1 \mathrm{a}$ \\
June & $47.7 \mathrm{~b}$ & $64.8 \mathrm{bc}$ & $36.3 \mathrm{bc}$ & $148.8 \mathrm{~b}$ \\
November & $70.0 \mathrm{a}$ & $97.8 \mathrm{a}$ & $49.1 \mathrm{ab}$ & $216.9 \mathrm{a}$ \\
F test & $*$ & $* *$ & $* * *$ & $* *$
\end{tabular}

${ }^{\mathrm{z}}$ Standard grower practice.

'Mean separation within columns by Duncan's multiple range test, $P \leq$ 0.05 .

Ns, ${ }^{* * *, * * *}$ Nonsignificant or significant at $P=0.05,0.01$, or 0.001 , respectively.

Table 5. Effect of time and amount of soil-applied $\mathrm{N}$ on leaf $\mathrm{N}$ concentration.

\begin{tabular}{lccc}
\hline \hline Month extra & \multicolumn{3}{c}{ Leaf N concn $(\%)^{\mathrm{z}}$} \\
\cline { 2 - 4 } $\mathrm{N}$ applied & Year 1 & Year 3 & Year 4 \\
\hline None $^{\mathrm{y}}$ (control) & 2.10 & 2.00 & $1.79 \mathrm{~b}^{\mathrm{x}}$ \\
January $^{\prime}$ & 2.15 & 2.04 & $1.87 \mathrm{ab}$ \\
February & 2.18 & 2.08 & $1.89 \mathrm{ab}$ \\
April & 2.16 & 2.08 & $2.00 \mathrm{a}$ \\
June & 2.20 & 2.05 & $1.94 \mathrm{a}$ \\
November & 2.19 & 2.07 & $1.92 \mathrm{ab}$ \\
F test & NS & NS & $*$ \\
\end{tabular}

${ }^{\mathrm{Z}}$ Leaf analyses were not done in Year 2.

yStandard grower practice.

xMean separation within columns by Duncan's multiple range test, $P \leq$ 0.05 .

Ns, ${ }^{*}$ Nonsignificant or significant at $P=0.05$, respectively.

together, results of this study suggest that in California, the 'Hass' avocado tree is not able to use $\mathrm{N}$ applied during January and February. Since N uptake from soil is likely a function of sink strength, the effect that application time had on yield must be due to providing extra $\mathrm{N}$ at times of competition between reproductive and vegetative sinks (Rosecrance et al., 1996). This might explain why leaf $\mathrm{N}$ concentration is not typically related to yield. The double dose of $\mathrm{N}$ in November significantly increased average and cumulative yields and fruit size. However, total leaf $\mathrm{N}$ concentrations were the same as those of control trees receiving less $\mathrm{N}$. Trees receiving the double dose of $\mathrm{N}$ in June accumulated $\mathrm{N}$ in leaves compared to control trees, but yielded the same as the control trees with regard to average and cumulative total kilograms and kilograms large size fruit per tree. Thus, it is clear that when $\mathrm{N}$ is applied to the soil in June it is not allocated to the fruit. The capacity of trees receiving the double dose of $\mathrm{N}$ in April for increased cumulative yield, more large size fruit, and reduced alternate bearing is likely due to having adequate $\mathrm{N}$ for both fruit set and fruit development and growth of the vegetative flush that bears the following year's inflorescences. With the exception of year 1 of this study, there was also a crop from the previous bloom on the trees competing for resources. Since 'Hass' avocado in California is harvested 10 to 18 months after bloom, the fruit could potentially benefit from the double dose of $\mathrm{N}$ two times during its development. The double dose of $\mathrm{N}$ applied later in fruit development might have a greater impact on fruit size. This might be especially true for trees receiving the double dose of $\mathrm{N}$ in November since inflorescence development was just occurring at the time of the first application.

Since applying additional $\mathrm{N}$ in January, February, and June to 'Hass' avocado trees had no effect on yield, fruit size, or alternate bearing, shifting the $\mathrm{N}$ applied in these months to November and April would appear warranted. This strategy would reduce the number of times $\mathrm{N}$ is applied to the soil. Thus, an increase in yield and fruit size or a decrease in alternate-bearing index obtained by this strategy would be achieved with no additional expense to the grower. The cost to the environment in terms of potential groundwater pollution from the higher rate of $\mathrm{N}$ per application remains to be determined.

\section{Literature Cited}

Bekey, R. 1989. Avocado timetable. California Grower 13:28-30.

Embleton, T.W. and W.W. Jones. 1965. Avocado nutrition in California. Proc. Fla. State Hort. Soc. 99:401-405.

Embleton, T.W. and W.W. Jones. 1972. Development of nitrogen fertilizer programs for California avocados. Calif. Avocado Soc. Yrbk. 56:90-96.

Embleton, T.W., W.W. Jones, and M.J. Garber. 1959. Leaf analysis as a guide to nitrogen fertilization of the Hass avocado. Calif. Avocado Soc. Yrbk. 43:94-95.

Embleton, T.W., W.W. Jones, M.J. Garber, and S.B. Boswell. 1968. Nitrogen fertilization of the Hass avocado. Calif. Avocado Soc. Yrbk. 52:131-134.

Embleton, T.W., W.W. Jones, and J.D. Kirkpatrick. 1955. Avocado fertilizer experiments. Calif. Avocado Soc. Yrbk. 39:62-66.

Embleton, T.W., W.W. Jones, C.K. Labanauskas, and W.J. Reuther. 1973. Leaf analysis as a diagnostic tool and guide to fertilization, p. 183-211. In: W.J. Reuther (ed.). The citrus industry. vol. 3. Univ. Calif. Div. Agr. Sci., Berkeley.

Kalmer, D. and E. Lahav. 1976. Water requirement of the avocado tree in the Western Galilee (1968-1974). Pamphlet 157. Div. Sci. Publ., Bet Dagan, Israel.

Kotzé, J.M. 1982. Phases of seasonal growth of the avocado tree. Citrus and Subtropical Fruit J. 586:9-11.

Lahav, E. 1998. Avocado nutrition-A review. Acta. Hort. 1:143-151. Lahav, E., Y. Bar, and D. Kalmar. 1990. Effect of nitrogenous fertilization on the annual variations in nutrients in avocado leaves. Commun. Soil Sci. Plant Anal. 21:1353-1365.

Langenegger, W. and T.J. Koen. 1978. Avokadobemesting-Jongste navorsingsresultate. Navorsingsverslag vir 1978: SAAKV 2:15-16.

Meyer, J.L., M.L. Arpaia, M.V. Yates, E. Takele, G. Bender, and G. Witney. 1991. Irrigation and fertilization management of avocados. Calif. Avocado Soc. Annu. Mtg., Ventura, Calif., 27 Sept. p. 33-48.

Rosecrance, R.C., S.A. Weinbaum, and P.H. Brown. 1996. Assessment of nitrogen, phosphorus, and potassium uptake capacity and root growth in mature alternate-bearing pistachio (Pistacia vera) trees. Tree Physiol. 16:949-956.

Salazar-Garcia, S. and C.J. Lovatt. 1998. Inflorescence and flower development of the 'Hass' avocado (Persea americana Mill.) during "on" and "off" crop years. J. Amer. Soc. Hort. Sci. 123:537-544. 